\title{
Trends and Features of Agroforestry Research Based on Bibliometric Analysis
}

\author{
Wenjing Liu ${ }^{1} \oplus$, Shuaichen Yao ${ }^{1}$, Jingsheng Wang ${ }^{2}$ and Moucheng Liu ${ }^{2, *}$ \\ 1 School of Environment and Natural Resources, Renmin University of China, Beijing 100872, China; \\ liuwenjing@ruc.edu.cn (W.L.); yaoshuaichen@yeah.net (S.Y.) \\ 2 Institute of Geographic Sciences and Natural Resources Research, Chinese Academy of Sciences, Beijing \\ 100101, China; wangjsh@igsnrr.ac.cn \\ * Correspondence: liumc@igsnrr.ac.cn
}

Received: 7 May 2019; Accepted: 18 June 2019; Published: 25 June 2019

\begin{abstract}
The world is faced with dual challenges to ensure food security for its large and still growing population and to mitigate climate change. It is necessary to develop more diversified and multifunction agricultural systems to address the challenges. Therefore, as a reasonable land use practice, agroforestry has become the hotspot in scientific research in recent decades. This study performed quantitative and qualitative analyses of agroforestry research published between 1990 and 2018 based on bibliometric methods, expecting to guidance for further research in order to scientifically understand of the trends and features of agroforestry research over time and by region. A total of 4204 publications were obtained from Web of Science. The results show that the research interest in the agroforestry field has significantly enhanced, and about 139 countries have been involved with the research in this field. These publications cover 66 subject categories and a great diversity research theme. Since 1990, the popular keywords in agroforestry research have been changed from "Intercropping", "Alley cropping", and "Multipurpose trees" to "Carbon sequestration", "Ecosystem service", and "Climate change". This indicates that the theme of agroforestry research has changed and the research scale is gradually expanding. Furthermore, agroforestry research themes vary with regions, since different regions have various requirements on the function of the agroforestry system. In the end, given the current trend of agroforestry science, we conclude a list of research potentials of agroforestry in the future.
\end{abstract}

Keywords: agroforestry; agricultural diversity; ecosystem services; bibliometric analysis

\section{Introduction}

Cultivating trees and agriculture crops/animals on the same unit of land is an ancient practice that has been practiced around the world for centuries. However, the traditional method has been replaced by intensive monoculture agriculture or forestry with the development of modern agriculture [1]. Until 1970s, tropical deforestation, ecological degradation, and food situation deterioration promoted the general acceptance of agricultural diversity. Agroforestry, which can resolve environment problems and/or economic problems and provide benefits to producers and the public, was again recognized as a sustainable agricultural practice [2,3]. Therefore, in 1977, the International Council for Research in Agroforestry (ICRAF) was established and agroforestry became an independent discipline that received extensive attention.

There are various definitions of agroforestry. The ICRAF defines "agroforestry is the interaction of agriculture and trees, including the agricultural use of trees. This includes trees on farms and contained in agricultural landscapes, farming in forests and along forest margins, and tree-crop production, including cocoa, coffee, rubber, and oil palm. Interactions between trees and other components of 
agriculture may be important at a range of scales: in fields (where trees and crops are grown together), on farms (where trees may provide fodder for livestock, fuel, food, shelter, or income from products, including timber), and landscapes (where agricultural and forest land uses combine in determining the provision of ecosystem services)" [4]. The Food and Agriculture Organization of the United Nations (FAO) defines it as "a collective name for land-use systems and technologies where woody perennials (trees, shrubs, palms, bamboos, etc.) are deliberately used on the same land-management units as agricultural crops and/or animals, in some form of spatial arrangement or temporal sequence" [5]. The United States Department of Agriculture (USAD) National Agroforestry Center (NAC) defines "agroforestry is the intentional integration of trees and shrubs into crop and animal farming systems to create environmental, economic, and social benefits" [6]. In conclusion, the agroforestry system is a land use practice with productivity, sustainability, and adoptability [2].

A great deal of scientific research over the past half-century has demonstrated that agroforestry may help to solve the problems that the world is facing today [7,8]. Many governments and non-governmental organizations have recognized these advantages and have incorporated it in regional/national development plans. Under this trend, the agroforestry system has rapidly developed around the world. The study of Zomer et al. has shown that about $46 \%$ of global agricultural land has tree coverage of more than $10 \%$, which influences about $30 \%$ of local rural populations [9]. Moreover, the extensive agroforestry practice, in turn, promotes the development of research. The rapid development of agroforestry research and practices led us to investigate what the trends and features are, where there are gaps, and where is the hidden opportunity of agroforestry research in recent years. A bibliometric analysis can provide a new perspective regarding knowledge status, features, and trends in a specific field $[10,11]$. A quantitative analysis can help the people who are unfamiliar, but interested, in this field, including managers and researches, to quickly grasp the basic information and development status of this field. Currently, bibliometric analysis has been widely applied in research regarding agriculture [12], forestry [13], greenhouse gas emissions [14], and some other fields. For instance, Montambault, J.R. and Alavalapati, J.R.R. reviewed the literature about socioeconomic issues in agroforestry research from 1992 to 2002 [15]. Leal, A.I. et al. carried bibliometric and network analyses to uncover the patterns, gaps, and constraints in cork oak silvopastoral systems scientific research [16]. However, to the best of our knowledge, few studies have attempted to comprehensively review agroforestry scientific development based on bibliometric methods over time and by region. This paper conducts bibliometric analysis to investigate the performance of agroforestry related articles published from 1990 to 2018 to fill this research gap and facilitate the development of the research. The goals of this study include the following aspects: (1) identifying the characteristics of the publication, such as the number of publications, representative countries, and research subjects; (2) recognizing the knowledge base according to the common cited references; (3) uncovering the changing trend of research themes over time and by region; and, (4) identifying the opportunities for future research.

\section{Methods and Materials}

Bibliometrics can quantitatively analysis the academic literature, such as journals, authors, countries, and institutions. This methodology has been used in numerous researches and the detailed description can been found in our previous studies [11,17]. Bibliometric analysis can be achieved through software, such as BibExcel and CiteSpace. BibExcel was used in this study due to its flexibility. Except for the basic bibliometric analysis, citation analysis, co-citation, and bibliographic coupling analysis, BibExcel also can produce net-files for co-occurrence analysis, which Pajek, NetDraw, or Gephi can map for further analysis. More information about Bibexcel can be found at http://homepage.univie.ac.at/juan.gorraiz/bibexcel/.

Web of Science (WoS) is a typical online academic database. This database covers the journals of science, technology, social sciences, and more. The data of this study were collected from the ISI Web of Science Core Collection (WoSCC) database. The retrieval strategy is "AK = Agroforestry OR KP = 
Agroforestry OR TI = Agroforestry" (AK is Author Keywords, KP is Keywords Plus, and TI is Title). We selected "article" from the "document types" option and "English" in the "languages" option for further analysis in this paper to clarify the type of data. Accordingly, the data span of this study is from 1990 to 2018. A total of 4204 publications were selected on 11 January 2019.

\section{Results}

\subsection{Overview of the Publication Characteristics}

As shown in Figure 1, the number of annual publications exhibited an increasing trend, from 43 articles in 1990 to 385 articles in 2018. The greatest growth occurred in 2007-2018, during which $66.46 \%$ of the articles were published.

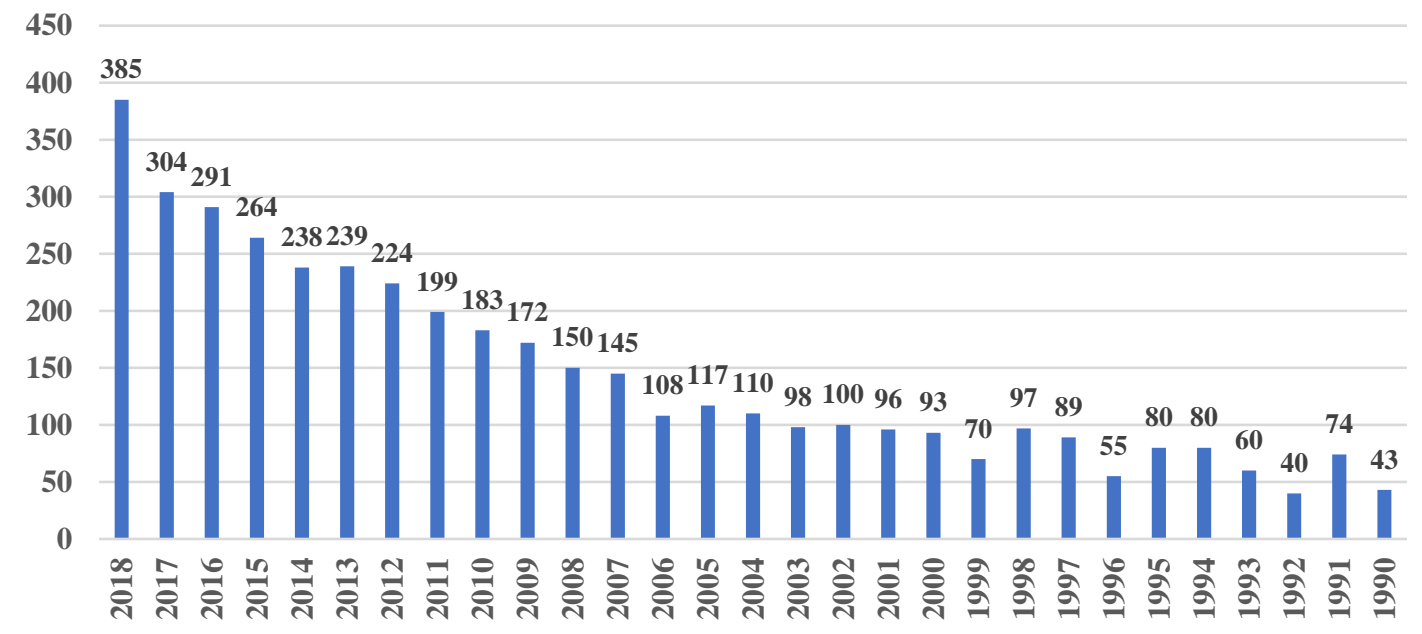

Figure 1. Annual number of publications from 1990-2018.

A total of 139 countries/regions published agroforestry related researches from 1990 to 2018. Among these countries, 15 countries have published more than 100 articles (Figure 2). The United States of America (USA) $(958,22.79 \%)$ published the most articles, followed by India $(414,9.85 \%)$ and Germany (360, 8.56\%). Obviously, the USA, India, and Germany have paid a great deal of attention to this field. Nearly half of the top 15 representative countries (7/15) were developing countries.

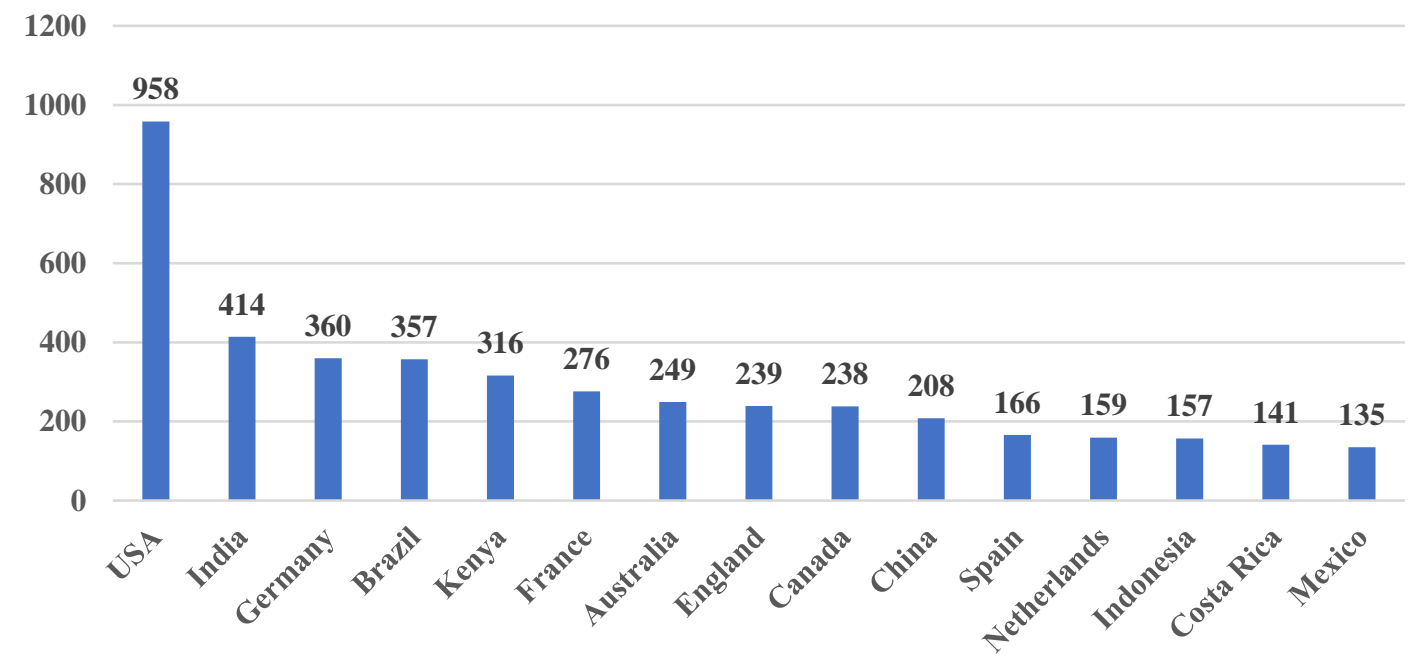

Figure 2. The performance of the top 15 representative countries. (TP $\geq 100)$.

The 4204 articles that were reviewed in this study were divided into six primary groups and 66 subject categories, according to WoS subject categories. The six primary groups include Arts \& 
Humanities, Social Sciences, Life Sciences \& Biomedicine, Physical Sciences, and Technology, and Science \& Technology (Other Topics). As shown in Figure 3, the most productive primary group are Life Sciences \& Biomedicine (85.61\%), and the three most common subject categories were Agriculture (34.67\%), Forestry (22.64\%), and Environmental Sciences \& Ecology (16.45\%). The other five primary group only account for $14.39 \%$. The common subject categories in the five primary groups are Water Resources (1.65\%), Business \& Economics (1.39\%), and Engineering (1.07\%). In conclusion, agroforestry science has been one of the important areas in both natural science and social science.

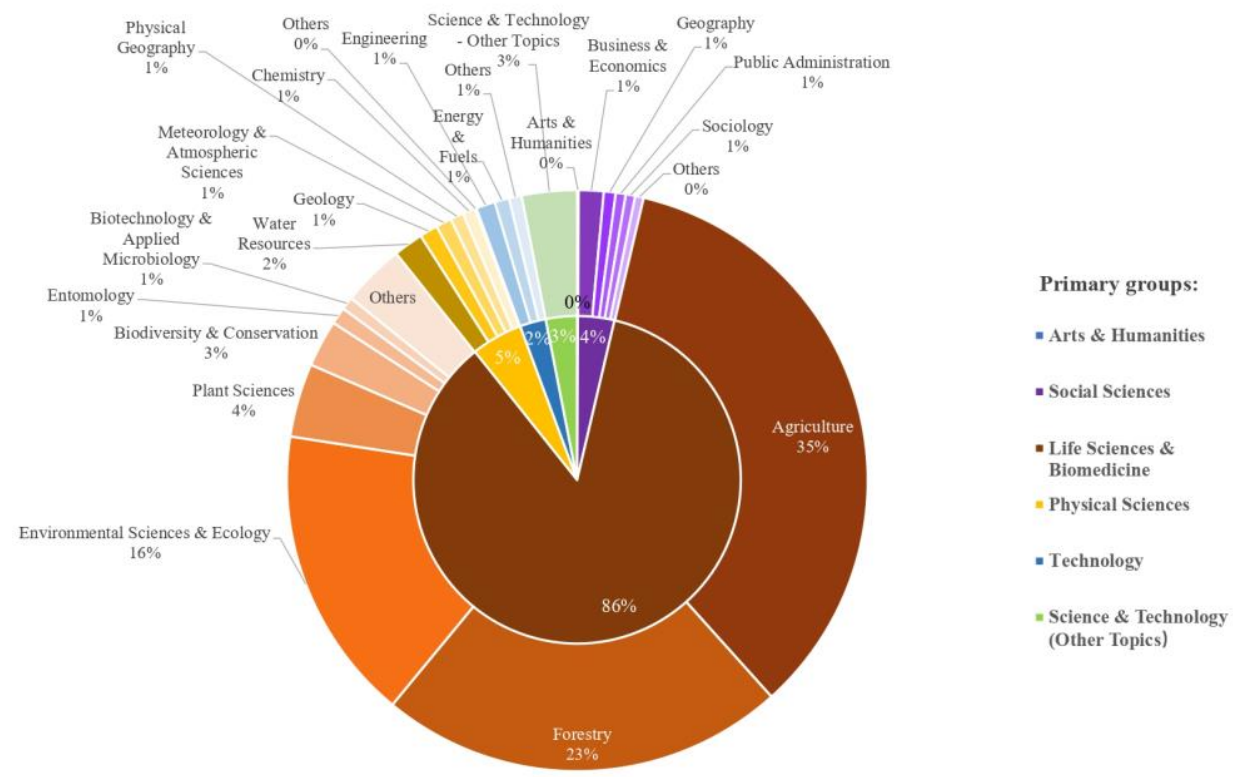

Figure 3. Six primary groups (inner) and main subject categories (outer).

\subsection{Most Cited References}

The commonly cited references of a specific research area can reveal the knowledge base of this field [18]. Table 1 lists the basic information regarding the 11 most frequently cited references in the articles from 1990-2018 in the agroforestry field, such as the total referenced frequency, article titles, author names, publication years, and journal titles/publisher. The most highly cited reference is "Agroforestry for ecosystem services and environmental benefits: an overview", as authored by Jose, S. [19] in Agroforestry Systems. This comprehensive review briefly discusses the ecosystem services and environmental benefits that are provided by agroforestry from four perspectives-carbon sequestration, soil enrichment, biodiversity conservation, and air/water quality. The research with the second-highest number of citations is titled "Science in agroforestry", as authored by P. A. Sanchez [20] and published in Agroforestry Systems in 1995. This article proposed that "agroforestry research is being transformed from a collection of largely descriptive studies into more scientific approaches, based on process-oriented research". This article systematically discussed four key features of agroforestry-competition, complexity, profitability, and sustainability, and pointed out the future research direction. The third most cited reference is a book, "An Introduction to Agroforestry", which was published in 1993 [2]. This is the first book that systemically introduces agroforestry system. This book reviews the history of agroforestry and describes the current knowledge regarding the biophysical and socioeconomic sciences in agroforestry. The remaining eight most frequently cited references primarily focus on carbon sequestration [21-23], biodiversity [24,25], interspecific interactions [26], ecosystem services [27], and soil management [28]. 
Table 1. The 11 most frequently cited references from 1990-2019. (Frequency > 100).

\begin{tabular}{|c|c|c|c|c|}
\hline Frequency & Article & Author & Year & Journal/Publisher \\
\hline 169 & $\begin{array}{c}\text { Agroforestry for ecosystem services and environmental } \\
\text { benefits: an overview }\end{array}$ & Jose, $\mathrm{S}$. & 2009 & Agroforestry Systems \\
\hline 162 & Science in agroforestry & P. A. Sanchez & 1995 & Agroforestry Systems \\
\hline 161 & An Introduction to Agroforestry & Nair, P.K.R. et al. & 1993 & Springer \\
\hline 156 & Carbon sequestration in tropical agroforestry systems & Albrecht, A. and Kandji, S.T., & 2003 & Agriculture Ecosystems \& Environment \\
\hline 150 & $\begin{array}{c}\text { Carbon Sequestration: An Underexploited Environmental } \\
\text { Benefit of Agroforestry Systems }\end{array}$ & Montagini, F. and Nair, P.K.R. & 2004 & Agroforestry Systems \\
\hline 137 & Agroforestry as a strategy for carbon sequestration & Nair, P.K.R. et al. & 2009 & Journal of Plant Nutrition and Soil Science \\
\hline 125 & Shade coffee: a disappearing refuge for biodiversity & Perfecto, I. et al. & 1996 & Bioscience \\
\hline 119 & Agroforestry: A refuge for tropical biodiversity? & Bhagwat, S.A. et al. & 2008 & Trends in Ecology \& Evolution \\
\hline 105 & Interspecific interactions in temperate agroforestry & Jose, S. et al. & 2004 & Agroforestry Systems \\
\hline 102 & $\begin{array}{l}\text { Multifunctional shade-tree management in tropical } \\
\text { agroforestry landscapes-a review }\end{array}$ & Tscharntke, T. et al. & 2011 & Journal of Applied Ecology \\
\hline 102 & Agroforestry for soil management & Young, A. & 1997 & CABI \\
\hline
\end{tabular}




\subsection{Research Themes}

\subsubsection{Keyword Co-Occurrence}

A total of 9887 keywords appeared in the 4204 selected publications. The original data were pre-treated to make the results more reasonable. Similar keywords, such as "Ecosystem services" and "Ecosystem service"; "Agroforestry systems" and "Agroforestry system"; and, "Land-use change" and "Land use change" were merged. After a series of data management processes, there were a total of 9344 keywords. Among these keywords, 73.35\% appeared only once and 2.98\% appeared more than 10 times. Useful information, such as objectives, methods, and viewpoints, can be obtained from the keywords of a publication [29]. As shown in Figure 4, after excluding the words "Agroforestry" (1426 times) and "Agroforestry system" (200 times), the top three words were "Carbon sequestration" (133 times), "Biodiversity" (105 times), and "Intercropping" (100 times), which were also the most frequently mentioned keywords in research.

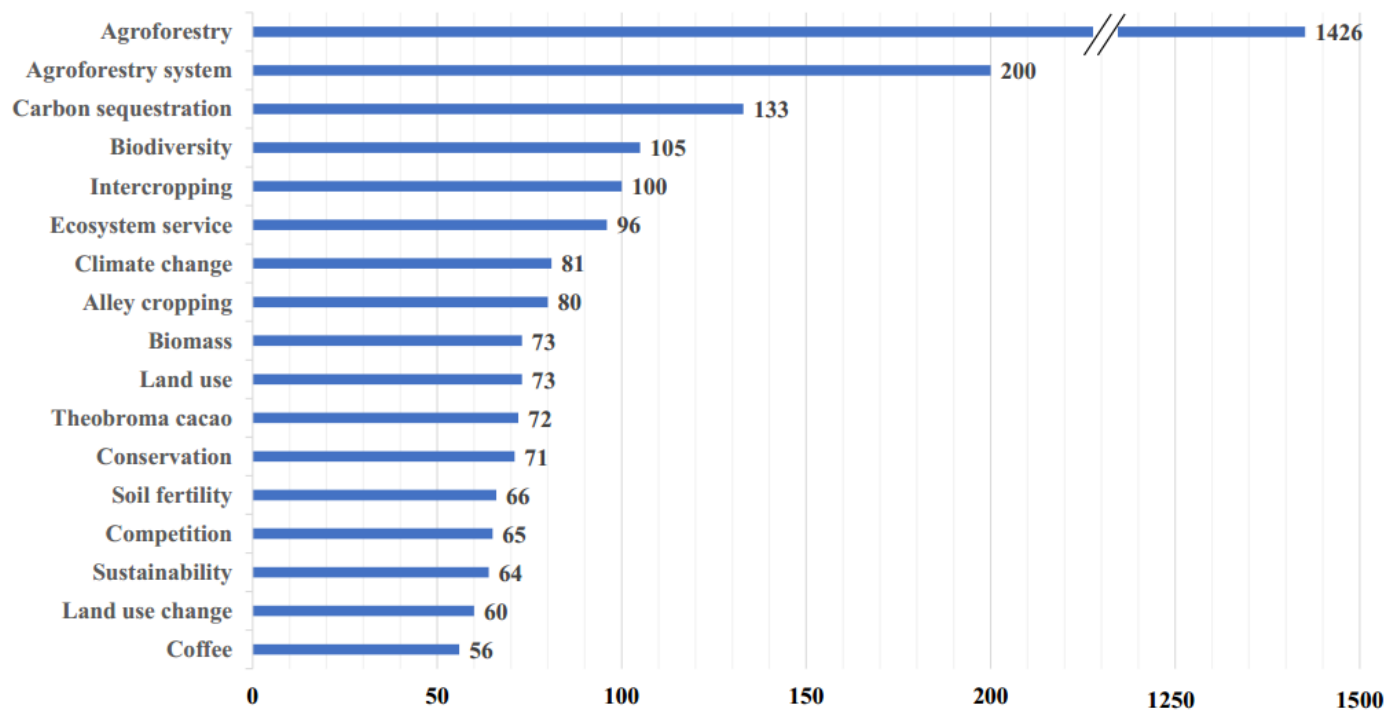

Figure 4. Top 17 most used keywords from 1990-2018.

Figure 5 shows the network of the 167 most frequently occurring keywords. The size of the circle represents the total collaboration frequency of a keyword; larger circles represent higher collaboration frequencies. Similarly, the width of the line indicates the collaboration frequency between two keywords. That is, a thicker line represents more frequent collaborations between the two keywords. Not surprisingly, "Agroforestry", as the keyword of this study, occupies the central position and intermediation. "Agroforestry" is strongly associated with "Carbon sequestration" (50 times), "Ecosystem service" (39 times), "Biodiversity" (39 times), "Coffee" (32 times), "Maize" (31 times), "Climate change" (30 times), and "Conservation" (30 times). Other strong associations include "Nitrogen" and "Phosphorus" (17 times), "Carbon sequestration" and "Soil organic carbon" (14 times), and "Biodiversity" and "Conservation" (11 times). 


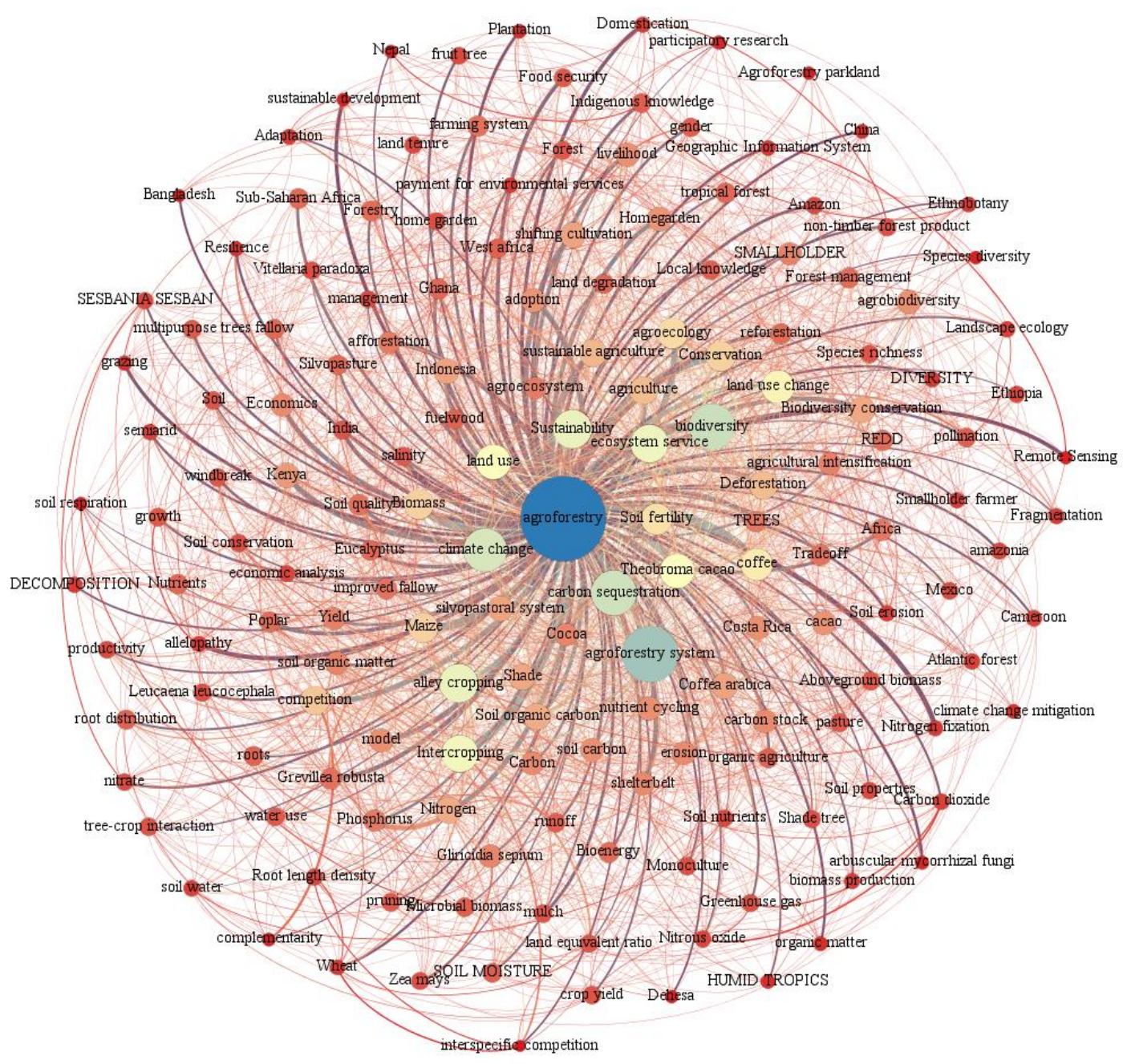

Figure 5. The network of the 167 most frequently occurring keywords (frequency $\geq 15$ ).

\subsubsection{Keyword Evolution in Four Periods}

Table 2 shoes the 12 most frequently used keywords during the four periods, which can provide an overview of the evolution of keywords during the last three decades. In terms of the use frequency, except for "Agroforestry", "Agroforestry system" increased the most significantly, from nine times during the 1990-1997 period to 128 times during the 2012-2018 period. Specifically, in the period of 1990-1997, except for "Agroforestry", "Intercropping" (16 times), "Alley cropping” (14 times), and "Economics" (12 times) were the most three frequently used keywords. "Competition" (30 times), "Alley cropping" (21 times), and "Intercropping" (18 times) were the most frequently used keywords in the period of 1998-2004. In the period from 2005 to 2011, "Carbon sequestration" (48 times), "Intercropping" (38 times), and "Biodiversity" (31 times) were the most commonly used keywords. In the period of 2012-2018, "Carbon sequestration" (88 times), "Ecosystem service" (82 times), and "Biodiversity" (67 times) were the most commonly used keywords. 
Table 2. The 12 most frequently used keywords during the four periods.

\begin{tabular}{|c|c|c|c|c|c|c|c|c|}
\hline & 1990-1997 & & 1998-2004 & & 2005-2011 & & 2012-2018 & \\
\hline 1 & Agroforestry & 178 & Agroforestry & 253 & Agroforestry & 348 & Agroforestry & 647 \\
\hline 2 & Intercropping & 16 & Competition & 30 & Agroforestry system & 48 & Agroforestry system & 128 \\
\hline 3 & Alley cropping & 14 & Alley cropping & 21 & Carbon sequestration & 38 & Carbon sequestration & 88 \\
\hline 4 & Economics & 12 & Intercropping & 18 & Intercropping & 31 & Ecosystem service & 82 \\
\hline 5 & Multipurpose trees & 11 & Kenya & 16 & Biodiversity & 27 & Biodiversity & 67 \\
\hline 6 & Shifting cultivation & 11 & Agroforestry system & 15 & Maize & 22 & Climate change & 64 \\
\hline 7 & Indonesia & 10 & Conservation & 15 & Theobroma cacao & 20 & Biomass & 44 \\
\hline 8 & On-farm research & 10 & Nitrogen & 15 & Biomass & 18 & Land use change & 43 \\
\hline 9 & Agroforestry system & 9 & Gliricidia sepium & 14 & Competition & 18 & Theobroma cacao & 41 \\
\hline 10 & Sustainability & 9 & Salinity & 14 & Land use & 18 & Land use & 39 \\
\hline 11 & Competition & 8 & Soil fertility & 14 & Conservation & 17 & Conservation & 36 \\
\hline 12 & Farming system & 7 & Maize & 13 & Silvopastoral system & 17 & Agroecology & 35 \\
\hline
\end{tabular}

\subsubsection{Keyword in Different Country/Regions}

Agroforestry, as a sustainable production practice, has been widely researched on a global scale. However, due to the considerable variations in climate, geographical features, historical factors, and economic conditions the development of global agroforestry research is unbalanced, and obvious region characteristics have been formed. Figure 6 provides the information in the 10 most frequently used keywords of the 10 most influential countries. Among these countries, three come from America, two from Asia, three from Europe, one from Oceania, and one from Africa. There are obvious differences among the common keywords in different countries. For instance, the most frequently used keywords (except "Agroforestry" and "Agroforestry system", the same as in the following) during 1990-2018 in the USA were "Carbon sequestration" (33 times), "Biodiversity" (29 times), and "Alley cropping" (28 times), while the most frequently used keywords in China were "Intercropping" (19 times), "China" (11 times), "Wheat" (seven times), and "Soil erosion" (seven times). 


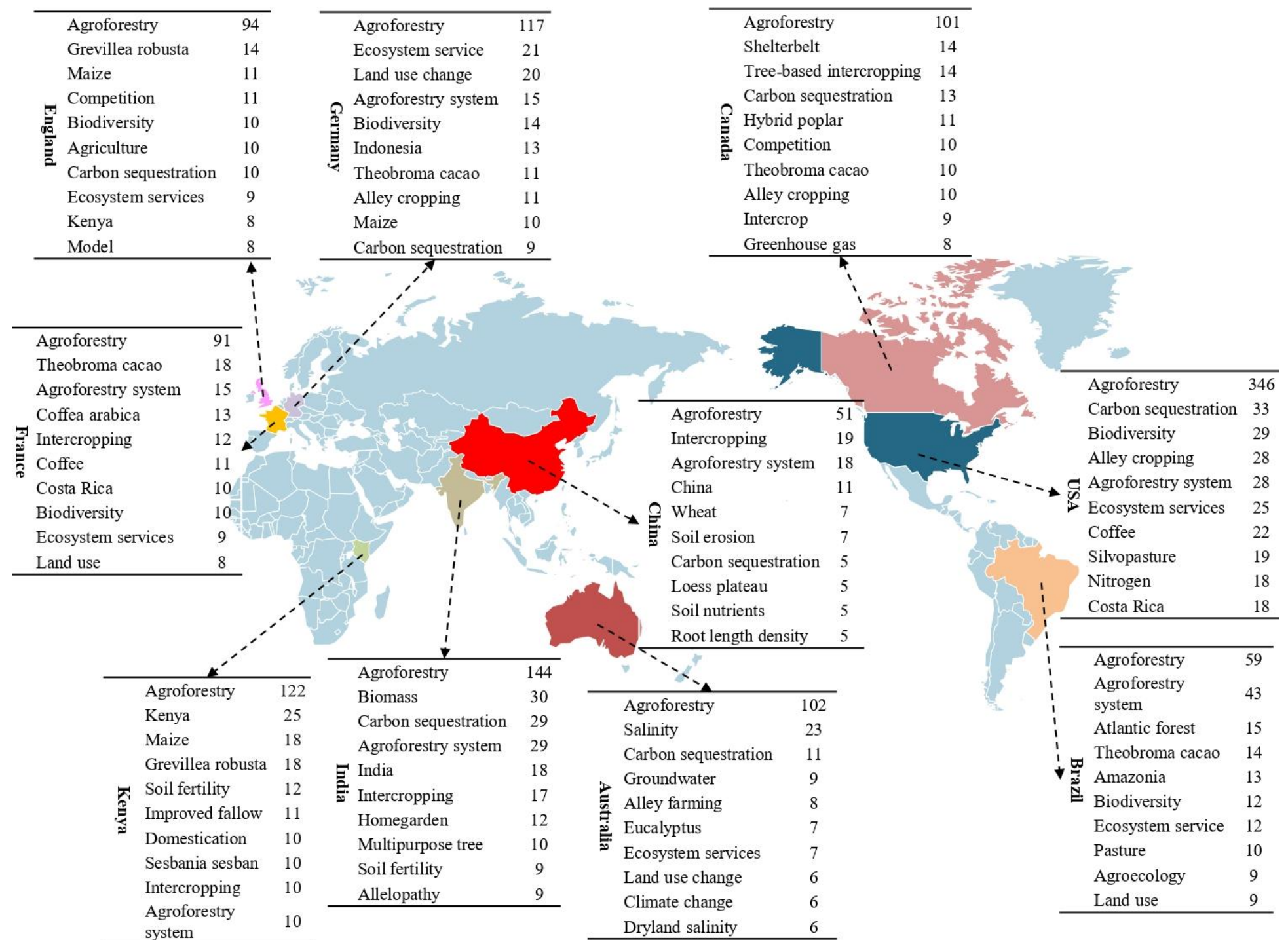

Figure 6. The 10 most frequently used keywords of the 10 most influential countries. 


\section{Discussion}

\subsection{Agroforestry is Attracting More and More Attention}

As agroforestry has received increasing attention, the number of annual publications increased from 43 in 1990 to 385 in 2018, and a total 139 countries/regions have published agroforestry related research from 1990 to 2018. In particular, ICRAF joined Consultative Group on International Agricultural Research (CGIAR) in 1991, and explicitly linked its work to the goals of CGIAR—reducing poverty, strengthening food security, and improving the environment [4]. This substantially promoted the development of agroforestry research in both developed countries and developing countries.

This attention may be related to the multifunction of agroforestry. Firstly, many of studies have proved that the agroforestry system can provide more diversified products and services. Specifically, agroforestry can provide a variety of products, such as fruit, grain, oils, etc. for food, fodder for livestock, timber, energy production, and medicines. Several studies have indicated that agroforestry can achieve more economic benefits than traditional agriculture. For instance, a financial analysis in Bangladesh indicated that the agroforestry system can provide a much higher net present value (NPV) than shifting cultivation, and agroforestry is more profitable and less risky [30]; the study in Cameroon indicated that approximately $64 \%$ of the farms obtain a positive net profit margin from their agroforestry investments [31]; and, a study of two typical agroforestry systems in China also proved that agroforestry has better financial benefits for farmers [32]. Secondly, in most countries, environment protection, in a local region, landscape, or global, is the pivotal factors that promote agroforestry development. According to the results of most cited references and the commonly used keyword, there is no doubt that ecosystem services, biodiversity, and carbon sequestration have received wide attention. Many studies have demonstrated that agroforestry is a land use strategy for slowing or halting deforestation, soil, and water conservation, biodiversity conservation, and poverty reduction. For example, by gathering 28 studies from all over the world, the results indicate that agroforestry can enrich soil organic carbon, improve soil nutrient and soil fertility, and enhance soil microbial dynamics [33]. A meta-analysis of 53 publications showed that agroforestry can enhance biodiversity as compared with the conventional agriculture and forestry in Europe [34]. Based on 86 publications that quantified the sequestration potential of agroforestry systems around the world, Feliciano et al. concluded that agroforestry systems can provide carbon sequestration services, especially in tropical climates [35]. Besides, agroforestry systems also provide services, such as: water regulation, micro-climates modifications, pest control, air cleaning, and so on [19]. Finally, agroforestry has great social benefit potential, such as reducing poverty and hunger, improving living standards, ensuring food security, and inheriting culture. Especially, agroforestry plays an important role to the livelihoods of the poor people in tropical regions. For instance, a study in southwestern Ethiopia showed that local agroforestry practices can support the food and nutrition security of smallholders in multiple ways [8], and studies in Northern Bangladesh [36]. Moreover, the cultural value of agroforestry systems can be presented through tourism and local actives [37].

\subsection{Agroforestry Research is Abundant and Emphasize Its Sustainability}

Agroforestry has four key features-competition, complexity, profitability, and sustainability [20]. Therefore, no single dimension can contribute to our holistic understanding of agroforestry system and help managers to make decisions of efficient and sustainable land use management [15]. Agroforestry is an integrative research field that involves the combined application of agriculture, forestry, ecology, economics, sociology, soil science, geography, zoology, and other applied sciences because of these features. Our analyses support the idea that agroforestry research contains more than 60 subject categories, including nature science, social science, and technology. However, the most common representative subject categories are Agriculture, Forestry, and Environmental Sciences \& Ecology, and research from the social science and technology aspect is relatively less. 
The research themes of agroforestry during the last 30 years have significantly changed. At the beginning of the 1990s, agroforestry researches mainly focused on describing the biophysical and socioeconomic performance in a successful and traditional agroforestry systems. As a result, the research in this period was inductive and experiential [38]. For instance, Szott, L.T. et al. evaluated three agroforestry systems in the humid tropics from the aspects of land, labor, and capital [39]. "Competition" has been a commonly used keyword around 2000, indicating that the structure of the agroforestry system became a popular research hotspot in this period. Researchers began to explore the component interactions of agroforestry system from theoretical and experimental aspects since the development of agroforestry system is based on the composition of the competition between trees and crops for light, water, and nutrients [20]. Besides, the interaction between species should be investigated to help managers to minimize interspecific competition and improve resource availability. For instance, a study of cocoa agroforestry system illustrates that shade trees can presumably enhance cocoa biomass [40] and another study in Brazil indicates that extrafloral nectaries of associated trees (Inga subnuda subsp. luschnathiana) can strengthen the natural pest control of coffee agroforestry systems [41]. Climate change was an acute global threat in the 20th century. The Kyoto Protocol proposed that agroforestry was a greenhouse gas-mitigation strategy [23]. Therefore, "Carbon sequestration" has become a key research theme and it still continues until now. Similarly, with the losses of natural habitats and biodiversity worldwide, people gradually realize the importance of biological diversity, and agriculture is one of the factors that have led to biodiversity losses [42]. Therefore, agroforestry, as a solution to halting deforestation and conserving biodiversity, has received increasing attention. Under this background, the concept of ecosystem services has been accepted, and the investigation on ecosystem services has become a hotspot. Considerable research has demonstrated that agroforestry can provide various ecosystem services in a spatial and temporal range [19]. Therefore, "Ecosystem services" has been a commonly used keyword in agroforestry research.

Accordingly, the research content of agroforestry is gradually abundant and the research scope has been expanded from the traditional local scales to regional and global scales [38]. However, the sustainability of agroforestry system is always the research focus of agroforestry science.

\subsection{Research Themes Varies by Region}

Various agroforestry practices have been applied in different regions based on the broad definition and concept of agroforestry, and when considering the unique climates, soils, landscape, and other natural resource conditions. According to the keywords in different countries/regions, it can be concluded that the agroforestry research themes varies by region, which can be attributed to the fact that different countries/regions have a different requirement for system functions. For instance, agroforestry is one of the important land use types in Latin America in order to prevent deforestation in the Amazon. The research in this region mainly focuses on how to meet the short- and long-term economic benefits of farmers while halting deforestation. Therefore, the commercial silvopastoral system and shaded tree-crop system are the most common agroforestry practices in this region [43]. Similarly, in southeast Asia, where the vastly expanded populations press hard upon the limits of food, space, and natural resources, the first concern is the rational distribution and sustainable utilization of limited land resource to meet their food requirements. Accordingly, the agroforestry system in this region pays significant attention to agriculture components. Homegardens, taungya, shelterbelts, and windbreaks are widely practiced. Africa is considered to be the poorest continent on Earth, and the productivity of land and labor is relatively low. Therefore, agroforestry is recognized and applied as a best strategy to meet national development objectives in Africa, including improving the access to nutritious food, reducing poverty, and conserving and rehabilitating ecosystems. ICRAF, which is headquartered in Nairobi, Kenya, has successfully implemented a lot of projects and carried out many case studies in Africa. On the contrary, in USA and Europe with high living standards, the agroforestry related research mainly focuses on ecosystem services, landscape aesthetics construction, and the role in response to the global environment change. 


\subsection{Research Limitations}

Firstly, in this study, we analyzed the publications within strict limitations, in order to avoid obtaining irrelevant search responses. Therefore, we only considered the publications that contained "agroforestry" in author keywords, keywords plus, and title. Other synonyms, like agrisilviculture were not considered. Secondly, because of the limitations of language and databases, some excellent papers were not captured in this study. Finally, this study only analyzed the scientific development of agroforestry based on the characteristics of the quantity, while not considering the contents of the papers. Therefore, this study can be combined with content analysis for more in-depth analysis.

\section{Conclusions and Future Research}

This study can help researchers or policy makers to better understand how the agroforestry science has evolved over time and by region, where there are gaps and the hidden opportunities. In this study, we conducted a systematic and comprehensive review on the research on agroforestry by carrying out bibliometric analysis. A total of 4204 publications were selected from the WoSCC database in the period of 1990-2018. The result revealed that agroforestry research has received increasing attention and the number of annual publications exhibited an increasing trend. Developed and developing countries both actively participated in the research on agroforestry. These efforts provide a theoretical basis for the development of the discipline. Furthermore, the content of agroforestry research has become gradually abundant and the research themes vary from one place to another. The research covers more than 60 subject categories that were included in natural sciences, social sciences, etc. The environment benefits of the agroforestry system have gained significant attention. The socio-economic benefit was less represented in our research.

The future of research potential of agroforestry was summarized given the current development trend of agroforestry science. Firstly, it is important to understand the social drivers for agroforestry system development. Agroforestry is application-oriented research, and farmers will implement all scientific research achievements. However, there are a lot of factors that influence farmers' willingness to adopt agroforestry, such as, income, knowledge, policy, and gender [44,45]. Therefore, more social science research in agroforestry science is encouraged to identify the factors that influence the adoption of agroforestry. Secondly, trade-off analysis between environmental benefits and economic benefits is necessary. Sustainability is the biggest advantage of agroforestry, and most researchers often solely concentrate on environmental benefit, while farmers are only concerned about the immediate economic benefits and profits. Therefore, the balance between environment and economy is required to address in the future. Thirdly, it is crucial to evaluate the ecosystem services that are provided by the agroforestry system. The agroforestry system provides ecosystem services, such as climate regulation and soil formation, to all human beings, but these services are not included in the price. Therefore, monetary valuation that can offer critical information is encouraged for supporting decision-making in the agroforestry management, like the payment for ecosystem services. Fourthly, agroforestry system varies with regions, and the agroforestry development in different regions should adapt to local conditions. Accordingly, domestication and exploitation of indigenous trees, and the diversification of products, are the hot fields in agroforestry research, and will always be. Finally, the area under agroforestry management has been rapidly increasing in recent years, and demands for new technology are constantly emerging. However, research that is aimed at developing new technology is inadequate compared with theoretical research. Therefore, the research of agroforestry technology should be strengthened, and promote science and technology achievement transform.

Author Contributions: Conceptualization, W.L.; Funding acquisition, M.L.; Writing-original draft, W.L.; Writing-review \& editing, S.Y., J.W. and M.L.

Funding: This research was supported by the China National key R \& D plan (2017YFC0506402), China National Natural Science Foundation (41201586), and the International Exchange and Cooperation Project of Ministry of Agriculture of China "Conservation of Globally Important Agricultural Heritage Systems (GIAHS) in China in 2019". 
Conflicts of Interest: The authors declare no conflict of interest.

\section{References}

1. Lovric, M.; Rois-Diaz, M.; den Herder, M.; Pisanelli, A.; Lovric, N.; Burgess, P.J. Driving forces for agroforestry uptake in Mediterranean Europe: Application of the analytic network process. Agrofor. Syst. 2018, 92, 863-876. [CrossRef]

2. Nair, P.K.R. An Introduction to Agroforestry; Springer: Dordrecht, the Netherlands, 1993; Volume 3-12.

3. Wilson, M.H.; Lovell, S.T. Agroforestry-The Next Step in Sustainable and Resilient Agriculture. Sustainability 2016, 8, 574. [CrossRef]

4. ICRAF. About Agroforestry. Available online: http://www.worldagroforestry.org/ (accessed on 4 April 2019).

5. FAO. About agroforestry. Available online: http://www.fao.org/forestry/agroforestry/80338/en/ (accessed on 4 April 2019).

6. NAC. About Agroforestry. Available online: https://www.fs.usda.gov/nac/index.shtml\#about (accessed on 4 April 2019).

7. Kmoch, L.; Pagella, T.; Palm, M.; Sinclair, F. Using Local Agroecological Knowledge in Climate Change Adaptation: A Study of Tree-Based Options in Northern Morocco. Sustainability 2018, 10, 3719. [CrossRef]

8. Jemal, O.; Callo-Concha, D.; Van Noordwijk, M. Local Agroforestry Practices for Food and Nutrition Security of Smallholder Farm Households in Southwestern Ethiopia. Sustainability 2018, 10, 2722. [CrossRef]

9. Zomer, R.A.; Trabucco, A.; Coe, R.D.; Place, F. Trees on Farm: Analysis of Global Extent and Geographical Patterns of Agroforestry; ICRAF Working Paper; World Agroforestry Centre: Nairobi, Kenya, 2009.

10. Aleixandre-Benavent, R.; Aleixandre-Tudó, J.L.; Castelló-Cogollos, L.; Aleixandre, J.L. Trends in scientific research on climate change in agriculture and forestry subject areas (2005-2014). J. Clean. Prod. 2017, 147, 406-418. [CrossRef]

11. Liu, W.; Wang, J.; Li, C.; Chen, B.; Sun, Y. Using Bibliometric Analysis to Understand the Recent Progress in Agroecosystem Services Research. Ecol. Econ. 2019, 156, 293-305. [CrossRef]

12. Aleixandre-Tudo, J.L.; Castello-Cogollos, L.; Aleixandre, J.L.; Aleixandre-Benavent, R. Bibliometric and social network analysis in scientific research on precision agriculture. Curr. Sci. 2018, 115, 1653-1667. [CrossRef]

13. Uribe-Toril, J.; Ruiz-Real, J.L.; Haba-Osca, J.; Valenciano, J.D. Forests' First Decade: A Bibliometric Analysis Overview. Forests 2019, 10, 17. [CrossRef]

14. Zhang, C.; Xu, T.; Feng, H.; Chen, S. Greenhouse Gas Emissions from Landfills: A Review and Bibliometric Analysis. Sustainability 2019, 11, 2282. [CrossRef]

15. Montambault, J.R.; Alavalapati, J.R.R. Socioeconomic research in agroforestry: A decade in review. Agrofor. Syst. 2005, 65, 151-161. [CrossRef]

16. Leal, A.I.; Correia, R.A.; Palmeirim, J.M.; Bugalho, M.N. Is research supporting sustainable management in a changing world? Insights from a Mediterranean silvopastoral system. Agrofor. Syst. 2019, 93, 355-368. [CrossRef]

17. Chen, W.; Liu, W.; Geng, Y.; Brown, M.T.; Gao, C.; Wu, R. Recent progress on emergy research: A bibliometric analysis. Renew. Sustain. Energy Rev. 2017, 73, 1051-1060. [CrossRef]

18. Bornmann, L.; Marx, W. The Wisdom of Citing Scientists. J. Assoc. Inf. Sci. Technol. 2014, 65, 1288-1292. [CrossRef]

19. Jose, S. Agroforestry for ecosystem services and environmental benefits: an overview. Agrofor. Syst. 2009, 76, 1-10. [CrossRef]

20. Sanchez, P.A. Science in agroforestry. In Agroforestry: Science, Policy and Practice: Selected Papers from the Agroforestry Sessions of the IUFRO 20th World Congress, Tampere, Finland, 6-12 August 1995; Sinclair, F.L., Ed.; Springer: Dordrecht, The Netherlands, 1995; pp. 5-55.

21. Albrecht, A.; Kandji, S.T. Carbon sequestration in tropical agroforestry systems. Agric. Ecosyst. Environ. 2003, 99, 15-27. [CrossRef]

22. Montagnini, F.; Nair, P.K.R. Carbon sequestration: An underexploited environmental benefit of agroforestry systems. Agrofor. Syst. 2004, 61-62, 281.

23. Nair, P.K.R.; Kumar, B.M.; Nair, V.D. Agroforestry as a strategy for carbon sequestration. J. Plant Nutr. Soil Sci. 2010, 172, 10-23. [CrossRef] 
24. Perfecto, I.; Rice, R.A.; Greenberg, R.; van der Voort, M.E. Shade Coffee: A Disappearing Refuge for Biodiversity. BioScience 1996, 46, 598-608. [CrossRef]

25. Bhagwat, S.A.; Willis, K.J.; Birks, H.J.B.; Whittaker, R.J. Agroforestry: A refuge for tropical biodiversity? Trends Ecol. Evol. 2008, 23, 261-267. [CrossRef]

26. Jose, S.; Gillespie, A.R.; Pallardy, S.G. Interspecific interactions in temperate agroforestry. Agrofor. Syst. 2004, 61, 237-255. [CrossRef]

27. Tscharntke, T.; Clough, Y.; Bhagwat, S.A.; Buchori, D.; Faust, H.; Hertel, D.; Hölscher, D.; Juhrbandt, J.; Kessler, M.; Perfecto, I.; et al. Multifunctional shade-tree management in tropical agroforestry landscapes-A review. J. Appl. Ecol. 2011, 48, 619-629. [CrossRef]

28. Young, A. Agroforestry for Soil Management; CAB International: Wallingford, UK, 1997.

29. Tian, X.; Geng, Y.; Sarkis, J.; Zhong, S. Trends and features of embodied flows associated with international trade based on bibliometric analysis. Resour. Conserv. Recycl. 2018, 131, 148-157. [CrossRef]

30. Rahman, S.A.; Rahman, M.F.; Codilan, A.L.; Farhana, K.M. Analysis of the economic benefits from systematic improvements to shifting cultivation and its evolution towards stable continuous agroforestry in the upland of Eastern Bangladesh. Int. For. Rev. 2007, 9, 536-547. [CrossRef]

31. Molua, E.L. The economics of tropical agroforestry systems: the case of agroforestry farms in Cameroon. For. Policy Econ. 2005, 7, 199-211. [CrossRef]

32. Lu, J.B. Energy balance and economic benefits of two agroforestry systems in northern and southern China. Agric. Ecosyst. Environ. 2006, 116, 255-262. [CrossRef]

33. Dollinger, J.; Jose, S. Agroforestry for soil health. Agrofor. Syst. 2018, 92, 213-219. [CrossRef]

34. Torralba, M.; Fagerholm, N.; Burgess, P.J.; Moreno, G.; Plieninger, T. Do European agroforestry systems enhance biodiversity and ecosystem services? A meta-analysis. Agric. Ecosyst. Environ. 2016, 230, 150-161. [CrossRef]

35. Feliciano, D.; Ledo, A.; Hillier, J.; Nayak, D.R. Which agroforestry options give the greatest soil and above ground carbon benefits in different world regions? Agric. Ecosyst. Environ. 2018, 254, 117-129. [CrossRef]

36. Hanif, M.A.; Roy, R.M.; Bari, M.S.; Ray, P.C.; Rahman, M.S.; Hasan, M.F. Livelihood Improvements Through Agroforestry: Evidence from Northern Bangladesh. Small-Scale For. 2018, 17, 505-522. [CrossRef]

37. Moreno, G.; Aviron, S.; Berg, S.; Crous-Duran, J.; Franca, A.; de Jalon, S.G.; Hartel, T.; Mirck, J.; Pantera, A.; Palma, J.H.N.; et al. Agroforestry systems of high nature and cultural value in Europe: provision of commercial goods and other ecosystem services. Agrofor. Syst. 2018, 92, 877-891. [CrossRef]

38. Nair, P.K.R. Agroforestry - The Future of Global Land Use; Springer: Dordrecht, the Netherlands, 2012.

39. Szott, L.T.; Palm, C.A.; Sanchez, P.A. Agroforestry In Acid Soils Of The Humid Tropics. In Advances in Agronomy; Brady, N.C., Ed.; Academic Press: Cambridge, MA, USA, 1991; Volume 45, pp. 275-301.

40. Isaac, M.E.; Timmer, V.R.; Quashie-Sam, S.J. Shade tree effects in an 8-year-old cocoa agroforestry system: biomass and nutrient diagnosis of Theobroma cacao by vector analysis. Nutr. Cycl. Agroecosyst. 2007, 78, 155-165. [CrossRef]

41. Rezende, M.Q.; Venzon, M.; Perez, A.L.; Cardoso, I.M.; Janssen, A. Extrafloral nectaries of associated trees can enhance natural pest control. Agric. Ecosyst. Environ. 2014, 188, 198-203. [CrossRef]

42. Klein, A.-M.; Vaissière, B.E.; Cane, J.H.; Steffan-Dewenter, I.; Cunningham, S.A.; Kremen, C.; Tscharntke, T. Importance of pollinators in changing landscapes for world crops. Proc. R. Soc. B Biol. Sci. 2007, 274, 303. [CrossRef]

43. Somarriba, E.; Beer, J.; Alegre-Orihuela, J.; Andrade, H.J.; Cerda, R.; DeClerck, F.; Detlefsen, G.; Escalante, M.; Giraldo, L.A.; Ibrahim, M.; et al. Mainstreaming Agroforestry in Latin America. In Agroforestry-The Future of Global Land Use; Nair, P.K.R., Garrity, D., Eds.; Springer Netherlands: Dordrecht, the Netherlands, 2012; pp. 429-453. 
44. McGinty, M.M.; Swisher, M.E.; Alavalapati, J. Agroforestry adoption and maintenance: self-efficacy, attitudes and socio-economic factors. Agrofor. Syst. 2008, 73, 99-108. [CrossRef]

45. Evangelista, R.J.P.; Cruz, A.C.; Lasco, R.D. Knowledge, Attitude and Practice of Smallholder Farmers Regarding Climate Change and Agroforestry: A Case Study of Farmers in Penablanca, Cagayan. J. Environ. Sci. Manag. 2016, 1, 42-55.

(c)

(C) 2019 by the authors. Licensee MDPI, Basel, Switzerland. This article is an open access article distributed under the terms and conditions of the Creative Commons Attribution (CC BY) license (http://creativecommons.org/licenses/by/4.0/). 